\title{
THE IMPACT OF LONG-TIME CHEMICAL BONDS IN MINERAL-CEMENT-EMULSION MIXTURES ON STIFFNESS MODULUS
}

\author{
Bohdan DOŁŻYCKI*, Mariusz JACZEWSKI, Cezary SZYDŁOWSKI \\ Dept of Highway and Transportation Engineering, Gdańsk University of Technology, Gdańsk, Poland
}

Received 09 June 2017; accepted 25 September 2017

\begin{abstract}
Deep cold in-place recycling is the most popular method of reuse of existing old and deteriorated asphalt layers of road pavements. In Poland, in most cases, the Mineral-Cement-Emulsion mixture technology is used, but there are also applications combining foamed bitumen and cement. Mineral-Cement-Emulsion mixtures contain two different binding agents - cement as well as asphalt from the asphalt emulsion. Asphalt creates asphalt bonding (responsible for flexible behaviour), whereas cement generates hydraulic bonds (responsible for stiffness of the layer). Final properties of MineralCement-Emulsion mixtures are a result of a combination of both binding agents. While the stiffness of the material is unaffected by asphalt bonding, an increase in stiffness with time is visible for materials treated with hydraulic binders. This publication presents the change in stiffness modulus of Mineral-Cement-Emulsion mixtures by Simple Performance Test. For the analysis, two batches of specimens were used: the first was tested 28 days after compaction (period stated in Polish recommendations) and the second was tested 1.5 years after compaction. Analysis showed that after 1.5 years the stiffness modulus increased by about $10 \%$ in comparison to the 28 days after compaction. The change is minor but still significant. Unexpectedly, the level of the increase was unaffected by the combination of the binding agents (asphalt emulsion, cement).
\end{abstract}

Keywords: cement bonding, cold in-place recycling, Mineral-Cement-Emulsion mixtures, phase angle, stiffness.

\section{Introduction}

Deep cold in-place recycling belongs to the most commonly used types of recycling of existing old flexible pavements, especially when it comes to low-volume roads (local roads). Different types of binding agents and their combinations are used for cold in-place recycling. In Poland, the two most common technologies are MineralCement-Emulsion (MCE) mixtures and mixtures with a combination of foamed bitumen and cement. These two types of mixtures have been described in detail (Dołżcki, 2015; Iwański \& Chomicz-Kowalska, 2011; Iwański \& Chomicz-Kowalska, 2016; Kukiełka, 2007; Valentin, Čížková, Suda, Batista, Mollenhauer, \& Simnofske, 2016).

The two primary binding agents used in MCE mixtures are cement and emulsion. The reclaimed asphalt pavement used, usually originating from old, low-quality and highly deteriorated roads have low durability. On the other hand, the requirements stated for MCE mixtures are very high, especially for strength as well as resistance to water and frost action. The factors mentioned above result in high amounts of binding agents, mainly cement, being added to the mixture. Such approach is observed in Poland (GDDKiA, 2013) and Germany (FGSV, 2005).

The properties of the MCE mixture strongly depend on the proportions and interactions between the two binding agents used (Bocci, Grilli, Cardone \& Graziani, 2011; Theyse, Long, Harvey, \& Monismith, 2004). An addition of emulsion results in an increase in viscous behaviour (the pavement acts more similarly to a flexible pavement), an increase in internal integrity, a decrease in the risk of shrinkage cracking, an increase in resistance to water and frost action, as well as an increase in the fatigue life of the pavement. An excessive amount of emulsion, however, results in a decrease in stiffness modulus of the MCE mixture. An addition of cement positively influences an increase in stiffness modulus, tension strength, and resistance to water and frost action. Moreover, it allows achieving the relatively high initial strength of the MCE mixture, which is a desirable property for the best usage of the reconstructed pavement under technological traffic. Cement also accelerates dissolution of the asphalt emulsion. On the other hand, additional cement increases shrinkage of the embedded mixture, often resulting in shrinkage cracks

*Corresponding author. E-mail: bohdan.dolzycki@wilis.pg.gda.pl 
of the MCE layer and, as a result, in reflective cracking of asphalt layers of the pavement. Other authors (Chomicz-Kowalska \& Maciejewski, 2015; Uzarowski, Maher, \& Tighe, 2015) have described this problem.

The properties of an MCE mixture result from combining two binding agents responsible for two different types of chemical bonds. Asphalt emulsion generates asphalt bonding, which is responsible for the elastic behaviour of the embedded layer. Cement generates hydraulic bonds, which are responsible for stiffness of the layer. The type of cement used strongly influences the generated hydraulic bonds. The cement of higher classes or quick-setting cement has a higher chance of dominating the type of bonds in the Mineral-Cement-Mixture in comparison to typically used $32.5 \mathrm{~N}$ class cement. The dominating type of bond decides the overall behaviour of the MCE layer. It is advisable to design MCE mixtures in a way that supports the domination of asphaltic bonds, as they are responsible for decreasing the risk of shrinkage cracking. On the other hand, it is inadvisable to entirely omit hydraulic bonds, which are responsible for resistance to weather.

The primary purpose of this paper is to present the impact of the two different binding agents used for the change of MCE mixture parameters with time. The impact of binding agents content on stiffness modulus and phase angles of different MCE mixtures after 28 days of conditioning (regular period for evaluation of properties

Table 1. The composition of Mineral-Cement-Emulsion mixtures used

\begin{tabular}{|l|c|c|c|}
\hline \multirow{2}{*}{ Composition } & \multicolumn{3}{|c|}{ Mineral mixture } \\
\cline { 2 - 4 } & C2 & C4 & C6 \\
\hline Cement, \% & 2 & 4 & 6 \\
Fine aggregate 0/2, \% & 10 & 8 & 6 \\
Continuously graded aggregate $0 / 31.5, \%$ & 18 & 18 & 18 \\
Reclaimed asphalt pavement, \% & 70 & 70 & 70 \\
\hline
\end{tabular}

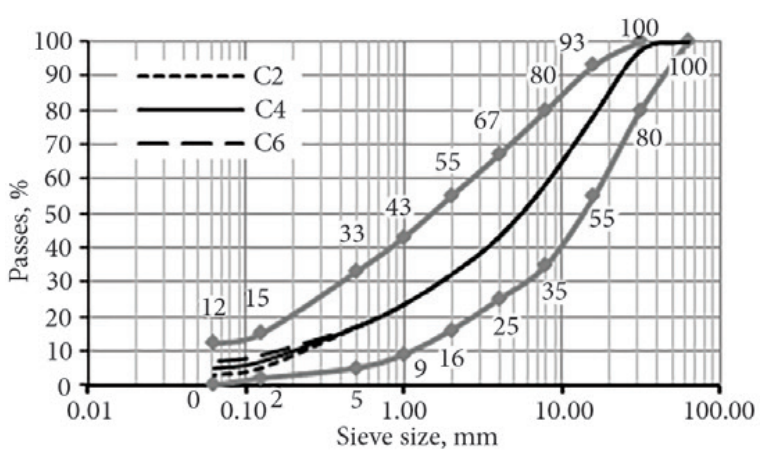

Figure 1. Grading curve of mineral mixtures of cement-bound materials) has been presented in another article by Dołżycki, Jaczewski, and Szydłowski (2017a, 2017b). Nevertheless, after 28 days the increase in stiffness still continues - due to further creation of hydraulic bonds - but at a slower rate. The rate of increase in stiffness modulus depends on cement content and the starting strength of the tested material (Neville, Ajdukiewicz, Degler, \& Kasperkiewicz, 2012).

Cement, one of the two binders used in MCE mixtures, is responsible for the increase in strength of materials with time. Conducted laboratory tests were to answer the question if (and to what extent) the longer time of binding affects the stiffness modulus and phase angles of the MCE mixture. The same specimens as in the previous test (Dołżycki, Jaczewski, \& Szydłowski, 2017a) were tested in the Simple Performance Tester 18 months after the initial compaction of the samples for the first test to analyse the phenomenon. The issue of time-related changes in MCE parameters is crucial and calls for due consideration as, with an increase in stiffness of the mixture, the risk of reflective cracking appearing at the surface of the pavement increases as well. Moreover, increase in the stiffness of the MCE mixture base course influences the fatigue life of the pavement structure.

\section{Materials}

The stiffness of the MCE mixture depends on the gradation of the mineral mixture, the amount and type of bitumen in reclaimed asphalt pavement and the combination of the binding agents used. The MCE mixture was designed according to Polish recommendations to assess the influence of binding agents (GDDKiA, 2013). Single grading curve was designed as a combination of reclaimed asphalt pavement, continuously graded 0/31.5 mixture and 0/2 fine aggregate. The proportions of aggregates used are presented in Table 1, and the grading curve is presented in Figure 1. Designations of MCE mixtures were chosen as follows: "C" indicates the amount of cement and " $E$ " indicates the amount of asphalt emulsion. For example, an MCE mixture with $2 \%$ of cement and $4 \%$ of the asphalt emulsion is designated as C2E4. The tests were conducted for nine combinations of binding agents: $2 \%, 4 \%$ and $6 \%$ of each binding agent. The combinations and mixture designations are presented in Table 2.

The C60B5R asphalt emulsion was used in the conducted research. This type of emulsion is dedicated for cold in-place recycling in Poland. As for cement, a typical MCE I 32.5R cement was used.

Mineral-Cement-Emulsion mixtures were prepared in laboratory mixer according to the PN-EN 12697-35 stand-

Table 2. Designations of Mineral-Cement-Emulsion mixtures used in the study and the combination of binding agents

\begin{tabular}{|c|c|c|c|c|c|c|c|c|c|}
\hline \multirow{2}{*}{ Content, \% } & \multicolumn{9}{|c|}{ Mineral-Cement-Emulsion mixture (MCE) designation } \\
\hline & $\mathrm{C} 2 \mathrm{E} 2$ & $\mathrm{C} 2 \mathrm{E} 4$ & C2E6 & C4E2 & $\mathrm{C} 4 \mathrm{E} 4$ & C4E6 & C6E2 & $\mathrm{C} 6 \mathrm{E} 4$ & C6E6 \\
\hline cement & 2 & 2 & 2 & 4 & 4 & 4 & 6 & 6 & 6 \\
\hline emulsion & 2 & 4 & 6 & 2 & 4 & 6 & 2 & 4 & 6 \\
\hline
\end{tabular}


ard. The specimens were compacted in gyratory compactor according to the PN-EN 12697-31 standard. The limiting compaction ratio was set at $99 \%$. The specimens were compacted to $170 \mathrm{~mm}$ height and $100 \mathrm{~mm}$ diameter. After 14 days of compaction, lower and upper surfaces were cut to reach the specimen height of $150 \mathrm{~mm}$. According to AASHTO TP79 (2013) procedure, the specimens are to be cut out of a larger specimen ( $150 \mathrm{~mm}$ diameter), but it was impossible due to the very low initial strength of the mixtures and high amount of coarse aggregates.

\section{Testing methods}

Stiffness modulus and phase angles were assessed in Simple Performance Tester according to the AASHTO TP79 (2013) standard. Specimens were subjected to dynamic haversine compressive load at three test temperatures: $4{ }^{\circ} \mathrm{C}, 20^{\circ} \mathrm{C}$ and $40^{\circ} \mathrm{C}$. For every mixture and every test temperature, three different specimens were tested in the controlled strain mode $(100 \mu$ strain). The strain was measured with three Linear Variable Differential Transformer sensors (gauge length of $70 \pm 1 \mathrm{~mm}$ ) attached to the specimen. Stiffness modulus and phase angles were measured at nine frequencies from $25 \mathrm{~Hz}$ to $0.1 \mathrm{~Hz}$ at temperatures of $4{ }^{\circ} \mathrm{C}$ and $20{ }^{\circ} \mathrm{C}$. At the temperature of $40{ }^{\circ} \mathrm{C}$, apart from nine primary frequencies, stiffness modulus and phase angles were measured at an extra frequency of $0.01 \mathrm{~Hz}$. The view of the specimen during the test is presented in Figure 2. All specimens were tested 28 days after compaction (first test).
Then samples were stored in the laboratory for 17 months, until they reached a total age of 1.5 years from compaction, and tested one more time (second test). Specimens were stored in a laboratory room, under typical temperature and moisture conditions without any individual conditioning.

\section{Test results}

Test results for three selected mixtures: C2E4, C4E4, and C6E4 are presented in Table 3. The relative and absolute changes in both stiffness modulus and phase angles measured after 28 days and 1.5 years are presented in

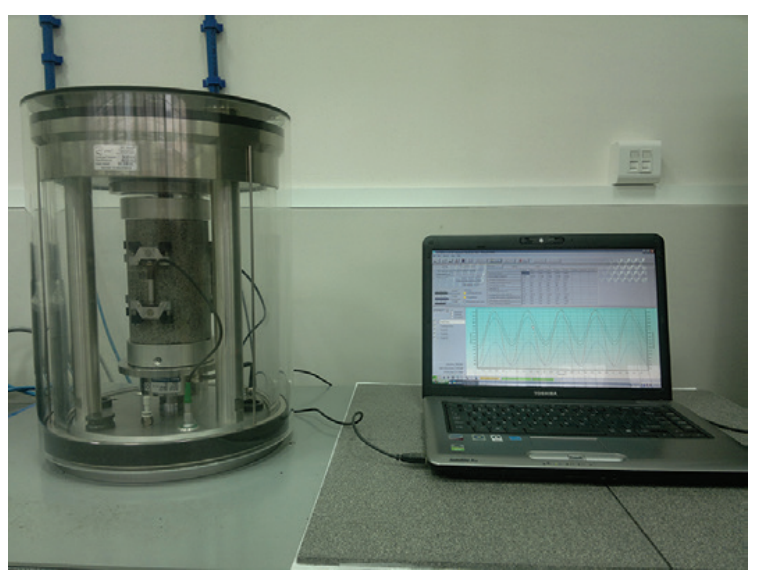

Figure 2. Specimen during the test in Simple Performance Tester according to the AASHTO TP79 (2013) standard

Table 3. Stiffness modulus moduli and phase angles for selected Mineral-Cement-Emulsion mixtures

\begin{tabular}{|c|c|c|c|c|c|c|c|c|c|}
\hline \multirow{3}{*}{$\begin{array}{c}\text { Mixture } \\
\text { designation }\end{array}$} & \multirow{3}{*}{$\begin{array}{c}\text { Temperature, } \\
{ }^{\circ} \mathrm{C}\end{array}$} & \multicolumn{4}{|c|}{ Stiffness modulus, $\mathrm{MPa}$} & \multicolumn{4}{|c|}{ Phase angle, ${ }^{\circ}$} \\
\hline & & \multicolumn{4}{|c|}{ Frequency, $\mathrm{Hz}$} & \multicolumn{4}{|c|}{ Frequency, $\mathrm{Hz}$} \\
\hline & & 10 & 1 & 0.1 & 0.01 & 10 & 1 & 0.1 & 0.01 \\
\hline \multirow{3}{*}{$\begin{array}{c}\text { C2E4 } \\
\text { (28 days) }\end{array}$} & 4 & 5456 & 4410 & 3344 & - & 8.51 & 10.58 & 13.21 & - \\
\hline & 20 & 2662 & 1758 & 1089 & - & 15.81 & 18.85 & 21.05 & - \\
\hline & 40 & 1006 & 524 & 293 & 193 & 23.63 & 23.52 & 20.92 & 16.69 \\
\hline \multirow{3}{*}{$\begin{array}{c}\text { C2E4 } \\
\text { (1.5 year) }\end{array}$} & 4 & 6153 & 5001 & 3891 & - & 8.02 & 9.82 & 12.19 & - \\
\hline & 20 & 3341 & 2323 & 1474 & - & 13.67 & 16.77 & 19.69 & - \\
\hline & 40 & 1196 & 624 & 331 & 212 & 22.92 & 24.11 & 22.36 & 20.41 \\
\hline \multirow{3}{*}{$\begin{array}{c}\text { C4E4 } \\
\text { (28 days) }\end{array}$} & 4 & 6993 & 5740 & 4513 & - & 7.54 & 9.39 & 11.80 & - \\
\hline & 20 & 4224 & 2946 & 1940 & - & 13.40 & 16.26 & 18.20 & - \\
\hline & 40 & 1580 & 918 & 581 & 423 & 20.57 & 19.70 & 16.71 & 12.14 \\
\hline \multirow{3}{*}{$\begin{array}{c}\text { C4E4 } \\
\text { (1.5 year) }\end{array}$} & 4 & 7200 & 5994 & 4815 & - & 6.76 & 8.37 & 10.49 & - \\
\hline & 20 & 4352 & 3072 & 2034 & - & 12.59 & 15.43 & 17.79 & - \\
\hline & 40 & 1895 & 1127 & 699 & 506 & 19.15 & 19.38 & 17.25 & 14.67 \\
\hline \multirow{3}{*}{$\begin{array}{c}\text { C6E4 } \\
\text { (28 days) }\end{array}$} & 4 & 8373 & 6983 & 5583 & - & 6.51 & 8.10 & 10.13 & - \\
\hline & 20 & 4997 & 3604 & 2485 & - & 11.95 & 14.34 & 15.85 & - \\
\hline & 40 & 2255 & 1427 & 963 & 721 & 17.99 & 17.20 & 14.61 & 10.93 \\
\hline \multirow{3}{*}{$\begin{array}{c}\text { C6E4 } \\
\text { (1.5 year) }\end{array}$} & 4 & 8739 & 7456 & 6156 & - & 5.95 & 7.27 & 9.02 & - \\
\hline & 20 & 5538 & 4101 & 2910 & - & 10.92 & 13.22 & 15.06 & - \\
\hline & 40 & 2504 & 1563 & 1011 & 746 & 17.37 & 17.62 & 15.78 & 13.48 \\
\hline
\end{tabular}


Table 4. The differences in values of stiffness moduli and phase angles measured after 28 days and after 1.5 years

\begin{tabular}{|c|c|c|c|c|c|c|c|c|c|}
\hline \multirow{4}{*}{$\begin{array}{c}\text { Mixture } \\
\text { designation }\end{array}$} & \multirow{4}{*}{ Temperature, ${ }^{\circ} \mathrm{C}$} & \multicolumn{4}{|c|}{ Stiffness modulus } & \multicolumn{4}{|c|}{ Phase angle } \\
\hline & & \multicolumn{4}{|c|}{ Frequency, $\mathrm{Hz}$} & \multicolumn{4}{|c|}{ Frequency, $\mathrm{Hz}$} \\
\hline & & 10 & 1 & 0.1 & 0.01 & 10 & 1 & 0.1 & 0.01 \\
\hline & & \multicolumn{4}{|c|}{ The absolute difference after 1.5 years, $\mathrm{MPa}$} & \multicolumn{4}{|c|}{ The absolute difference after 1.5 years, ${ }^{\circ}$} \\
\hline \multirow{3}{*}{$\mathrm{C} 2 \mathrm{E} 4$} & 4 & 697 & 591 & 547 & - & -0.49 & -0.76 & -1.02 & - \\
\hline & 20 & 679 & 565 & 385 & - & -2.14 & -2.08 & -1.36 & - \\
\hline & 40 & 190 & 100 & 38 & 19 & -0.71 & 0.59 & 1.44 & 3.72 \\
\hline \multirow{3}{*}{$\mathrm{C} 4 \mathrm{E} 4$} & 4 & 207 & 254 & 302 & - & -0.78 & -1.02 & -1.31 & - \\
\hline & 20 & 128 & 126 & 94 & - & -0.81 & -0.83 & -0.41 & - \\
\hline & 40 & 315 & 209 & 118 & 83 & -1.42 & -0.32 & 0.54 & 2.53 \\
\hline \multirow{3}{*}{$\mathrm{C} 6 \mathrm{E} 4$} & 4 & 366 & 473 & 573 & - & -0.56 & -0.83 & -1.11 & - \\
\hline & 20 & 541 & 497 & 425 & - & -1.03 & -1.12 & -0.79 & - \\
\hline & 40 & 249 & 136 & 48 & 25 & -0.62 & 0.42 & 1.17 & 2.55 \\
\hline & & \multicolumn{4}{|c|}{ The relative difference after 1.5 years, $\%$} & \multicolumn{4}{|c|}{ The relative difference after 1.5 years, $\%$} \\
\hline \multirow{3}{*}{$\mathrm{C} 2 \mathrm{E} 4$} & 4 & 13 & 13 & 16 & - & -6 & -7 & -8 & - \\
\hline & 20 & 26 & 32 & 35 & - & -14 & -11 & -6 & - \\
\hline & 40 & 19 & 19 & 13 & 10 & -3 & 3 & 7 & 22 \\
\hline \multirow{3}{*}{$\mathrm{C} 4 \mathrm{E} 4$} & 4 & 3 & 4 & 7 & - & -10 & -11 & -11 & - \\
\hline & 20 & 3 & 4 & 5 & - & -6 & -5 & -2 & - \\
\hline & 40 & 20 & 23 & 20 & 20 & -7 & -2 & 3 & 21 \\
\hline \multirow{3}{*}{$\mathrm{C} 6 \mathrm{E} 4$} & 4 & 4 & 7 & 10 & - & -9 & -10 & -11 & - \\
\hline & 20 & 11 & 14 & 17 & - & -9 & -8 & -5 & - \\
\hline & 40 & 11 & 10 & 5 & 3 & -3 & 2 & 8 & 23 \\
\hline
\end{tabular}
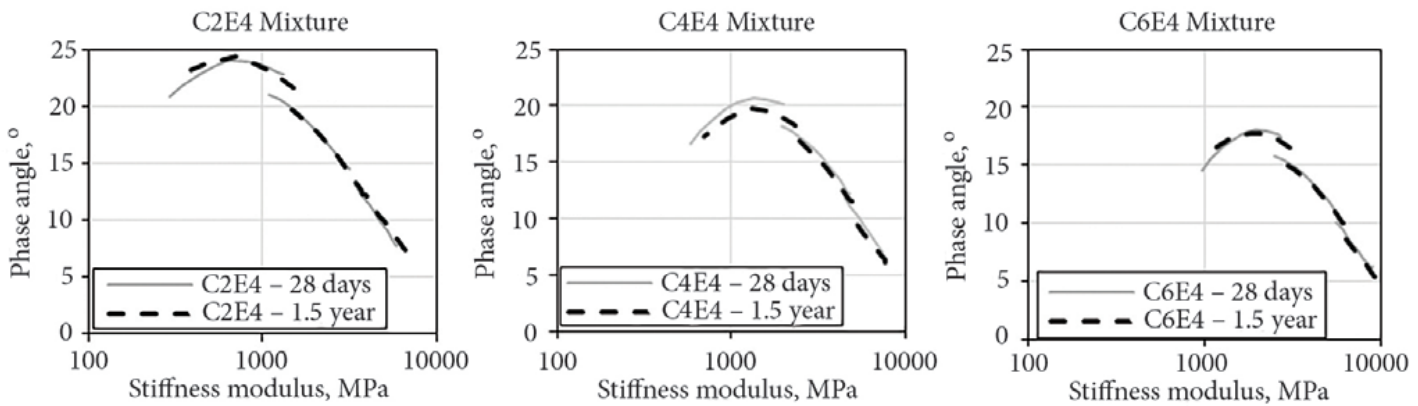

Figure 3. Black diagrams for selected Mineral-Cement-Emulsion mixtures

Table 4. The choice of representative mixtures was based on the impact of long-term storage on the behaviour of the binding materials used and the types of bonds developed in the material. From all the tested frequencies, $10 \mathrm{~Hz}, 1 \mathrm{~Hz}, 0.1 \mathrm{~Hz}$ and $0.01 \mathrm{~Hz}$ were chosen as the most representative for the presentation of the full behaviour of the mixtures. The results of both stiffness modulus and phase angles are presented for two test periods: 28 days and 1.5 years after compaction. The authors presented black diagrams and master curves for selected test results (Figures 3 and 4 respectively) to additionally present the change in the behaviour of selected mixtures. Additionally, for the selected temperature of $20^{\circ} \mathrm{C}$ and frequency of $10 \mathrm{~Hz}$, changes in stiffness modulus moduli and phase angles are presented in Figure 5.

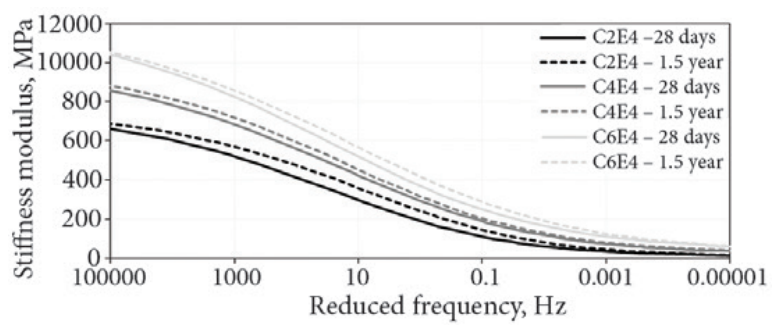

Figure 4. Master Curves for selected Mineral-Cement-Emulsion mixtures

Master Curves of stiffness were developed using the modified procedure presented in NCHRP 614 (2008) research report. Modifications were made by a literature review (Kleiziené, Vaitkus \& Čygas, 2016; Li, Zofka \& Yut, 2012; Pellinen, Witczak, Marasteanu, Chehab, Alavi, 

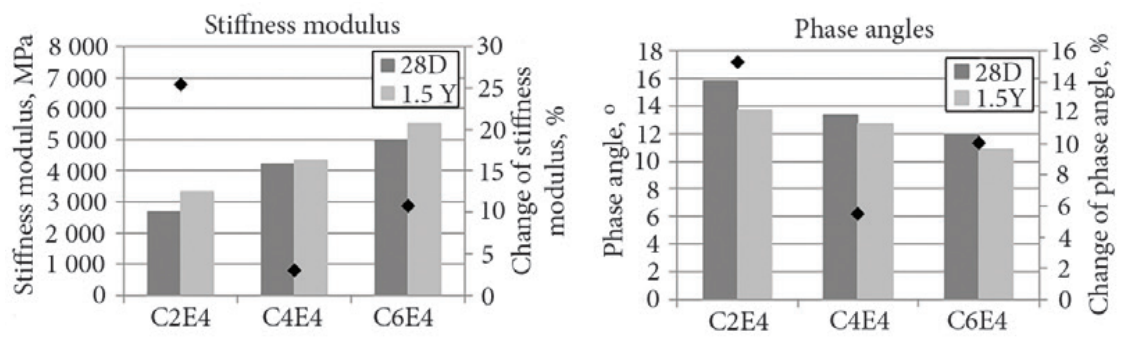

Figure 5. Stiffness modulus and phase angles of C2E4, C4E4, and C6E4 Mineral-Cement-Emulsion mixtures (frequency $10 \mathrm{~Hz}$, temperature $20^{\circ} \mathrm{C}$ ), bars represent the values obtained from laboratory tests, dots represent the relative change

\& Dongré, 2002; Rowe \& Sharrock, 2011; Zofka \& Yut, 2011). The used Eq. (1) assumed that shift factor was calculated using Arrhenius equation.

$$
\log \left|E^{*}\right|=\delta+\frac{(\operatorname{Max}-\delta)}{1+e^{\beta+\gamma}\left\{\log f+\frac{\Delta E_{a}}{19.14714}\left[\frac{1}{T}-\frac{1}{T_{R}}\right]\right\}},
$$

where $\left|E^{*}\right|$ - stiffness modulus, psi; Max - limiting maximum modulus, psi; $f$ - frequency, $\mathrm{Hz} ; T_{R}$ - reference temperature, $\mathrm{K} ; T$ - test temperature, $\mathrm{K} ; \delta, \beta, \gamma$ - fitting parameters; $\Delta E_{a}$ - activation energy (treated as a fitting parameter).

\section{Analysis and discussion of the laboratory test results}

The conducted laboratory tests showed the complex behaviour of MCE mixtures and complex changes in their mechanical properties. Whereas the combination of binding agents had a significant impact on mechanical properties of different mixtures, it had a lesser impact on the time-related change in the parameters. Nevertheless, it was observed that:

1. In most cases, tested mixtures with all combinations of binding agents showed an increase in stiffness modulus with time for all tested temperatures and frequencies. Usually, the relative increase ranged from $2 \%$ to $35 \%$, with a mean value of $13 \%$. The absolute maximum change in values of stiffness modulus reached $1000 \mathrm{MPa}$.

2. Some discrepancies were noted at the temperature of $4{ }^{\circ} \mathrm{C}$ for the following mixtures: C2E2, C2E6, and C4E6. For the highest frequencies $(10-25 \mathrm{~Hz})$ stiffness modulus decreased by $1 \%$ to $6 \%$ (by up to 500 $\mathrm{MPa}$ in absolute value).

3. At lower temperatures $\left(4^{\circ} \mathrm{C}\right)$, where both types of binders influence the stiffness of the mixture, the increase is lower than at higher temperatures $\left(40^{\circ} \mathrm{C}\right)$, where the stiffness of the material is influenced mainly by cement.

4. The increase in stiffness modulus of the MCE mixture with time is clear, and it is expected that stiffness modulus will further increase.

5. The changes in phase angles, in absolute values, were minor. On the other hand, taking into account the relative differences, it was more complex than the change in stiffness modulus. For most cases at temperatures of $4{ }^{\circ} \mathrm{C}$ and $20^{\circ} \mathrm{C}$ the value of phase angle decreased by $1 \%$ to $15 \%$, with a mean value of $5 \%$ (by up to $2^{\circ}$ in absolute value of phase angle). The only discrepancy was observed for the mixture $\mathrm{C} 2 \mathrm{E} 2$, where at the temperature of $4{ }^{\circ} \mathrm{C}$ at the highest frequencies phase angle increased by $2 \%$.

6. Strange behaviour was visible for the temperature of $40{ }^{\circ} \mathrm{C}$. Seven out of nine tested mixtures showed an increase in phase angle at the lowest frequencies (usually from $0.01 \mathrm{~Hz}$ to $2 \mathrm{~Hz}$ ). The observed relative change in phase angles was by up to $10 \%$ (by up to $1.5^{\circ}$ in absolute value of phase angle).

7. In the case of phase angles, the changes were usually minor, but the course of changes led to a more elastic response of the material.

8. Laboratory test results showed that the changes in parameters in the case of very low frequencies were different than in other cases. Whereas the changes in values of stiffness modulus presented the same behaviour regardless of the test frequency, greater changes were visible in the case of phase angles. All tested materials were expected to become more rigid with the curing time and the phase angles were expcted to decrease. That kind of behaviour was observed for higher frequencies $(25 \mathrm{~Hz})$, at which the values of phase angles decreased by around $10 \%$. Opposite behaviour was observed for lower frequencies $(0.01 \mathrm{~Hz})$, at which the material presented more behaviour that is viscous. The values of phase angles increased by around $20 \%$. This issue will be the primary scope of further research.

9. All tested materials presented the increase in the values of stiffness modulus. While the changes were relatively small, they indicated the increase in the importance of the hydraulic bonds. On the other hand, relatively high values of phase angles indicated that MCE mixtures still presented viscoelastic behaviour, due to the presence of bituminous bonds.

10. Laboratory test results showed that the change in the values of stiffness modulus and phase angles was uncorrelated to cement content. Cement content had a substantial impact on the starting values of stiffness modulus of all tested mixtures. It was especially obvious for higher frequencies. However, 
no plain correlations between the amount of specific binding agents and the changes in stiffness modulus or phase angles were found, but the observed trends for all tested MCE mixtures were the same.

\section{Conclusions}

The conducted laboratory tests showed that similarly to other cement-bound materials, Mineral-Cement-Emulsion mixtures show the increase in stiffness with time. While the absolute changes in the values of stiffness modulus and phase angles are rather low, the change is clear. It was also noted that the relative changes of stiffness modulus are higher than in the case of phase angles. Performed laboratory experiments indicated the increase of hydraulic bonds with time, what is visible in the increased value of the stiffness modulus. This kind of behaviour led to the small decrease of the bituminous bonds, what is visible by a small decrease in absolute values of the phase angles. Despite presented changes, Mineral-Cement-Emulsion mixtures still presented viscoelastic properties. Surprisingly, no obvious correlations between the amount of specific binding agents and the changes in stiffness modulus or phase angles were found.

\section{References}

AASHTO TP79. (2013). Standard Method of Test for Determining the Dynamic Modulus and Flow Number for Asphalt Mixtures Using the Asphalt Mixture Performance Tester (AMPT).

Bocci, M., Grilli, A., Cardone, F., \& Graziani, A. (2011). A study on the mechanical behaviour of cement-bitumen treated materials. Construction and building materials, 25(2), 773-778. https://doi.org/10.1016/j.conbuildmat.2010.07.007

Chomicz-Kowalska, A., \& Maciejewski, K. (2015). Multivariate optimization of recycled road base cold mixtures with foamed bitumen. Procedia Engineering, 108, 436-444. https://doi.org/10.1016/j.proeng.2015.06.168

Dołżycki, B. (2015). Badania mieszanek mineralno-cementowo-emulsyjnych (MCE). Budownictwo i Architektura, 14(4), 189-196 (in Polish).

Dołżycki, B., Jaczewski, M., \& Szydłowski, C. (2017a). The influence of binding agents on stiffness of mineral-cement-emulsion mixtures. Procedia Engineering, 172, 239-246. https://doi.org/10.1016/j.proeng.2017.02.103

Dolzycki, B., Jaczewski, M., \& Szydlowski, C. (2017b). The longterm properties of mineral-cement-emulsion mixtures. Construction and Building Materials, 156, 799-808. https://doi.org/10.1016/j.conbuildmat.2017.09.032

FGSV. (2005). Merkblatt für Kaltrecycling in situ im Straßenoberbau. Vol 636. FGSV. Forschungsgesellschaft für Straßen- und Verkehrswesen Arbeitgruppe Minneralstoffe im Straßen. Koln 2005.

GDDKiA. (2013). Instrukcja projektowania $i$ wbudowywania mieszanek mineralno-cementowo-emulsyjnych (MCE). Politechnika Gdańska. Retrieved from www.gddkia.gov.pl/ userfiles/articles/p/prace-naukowo-badawcze-w-trakcie_3434/ instrukcja\%20projektowania\%20i\%20wbudowywania $\% 20$ mieszanek\%20mineralno-cementowo-emulsyjnychwersja-12-12-2013.pdf

Iwański, M., \& Chomicz-Kowalska, A. (2011, May). The effects of using foamed bitumen and bitumen emulsion in the cold recycling technology. 8th International Conference on Environmental Engineering, Vilnius, Lithuania (pp. 1089-1096).

Iwański, M., \& Chomicz-Kowalska, A. (2016). Application of the foamed bitumen and bitumen emulsion to the road base mixes in the deep cold recycling technology. Baltic Journal of Road \& Bridge Engineering, 11(4), 291-301.

https://doi.org/10.3846/bjrbe.2016.34

Kleizienè, R., Vaitkus, A., \& Čygas, D. (2016). Influence of asphalt visco elastic properties on flexible pavement performance. Baltic Journal of Road \& Bridge Engineering, 11(4), 313-323. https://doi.org/10.3846/bjrbe.2016.36

Kukiełka, J. (2007). Trwałość podbudów z mieszanek mineralno-cementowo-emulsyjnych (MMCE). Budownictwo i Architektura, 1, 45-56 (in Polish).

Li, J., Zofka, A., \& Yut, I. (2012). Evaluation of dynamic modulus of typical asphalt mixtures in Northeast US region. Road materials and pavement design, 13(2), 249-265. https://doi.org/10.1080/14680629.2012.666641

NCHRP 614. (2008). National Cooperative Highway Research Program. NCHRP Report 614. Refining the Simple Performance Tester for Use in Routine Practice. Transportation Research Board. Washington D.C.

Neville, A. M., Ajdukiewicz, A., Degler, A., \& Kasperkiewicz, J. (2012). Właściwości betonu. Stowarzyszenie Producentów Cementu (in Polish).

Pellinen, T. K., Witczak, M. W., Marasteanu, M., Chehab, G., Alavi, S., \& Dongré, R. (2002, December). Stress dependent master curve construction for dynamic (complex) modulus. Asphalt Paving Technology: Association of Asphalt Paving Technologists-Proceedings of the Technical Sessions, 71, 281309. Association of Asphalt Paving Technologist.

PN-EN 12697-35. (2016). Bituminous mixtures. Test methods. Laboratory mixing.

PN-EN 12697-31. (2007). Bituminous mixtures. Test methods for hot mix asphalt. Specimen preparation by gyratory compactor.

Rowe, G. M., \& Sharrock, M. J. (2011). Alternate shift factor relationship for describing the temperature dependency of the visco-elastic behaviour of asphalt materials, Transportation Research Record, 2207, 125-135. https://doi.org/10.3141/2207-16

Theyse, H., Long, F., Harvey, J. T., \& Monismith, C. L. (2004). Discussion of Deep In-Situ Recycling (DISR). Technical Memorandum prepared for the California Department of Transportation. Pavement Research Center, Institute of Transportation Studies, University of California Berkeley, University of California Davis. UCPRC-TM-2004-6.

Uzarowski, L., Maher, M., \& Tighe, S. (2015). Green pavement technologies are sustainable only if they deliver acceptable performance. Proceedings of the Sixtieth Annual Conference of the Canadian Technical Asphalt Association (CTAA): Winnipeg, Manitoba, Canada.

Valentin, J., Čížková, Z., Suda, J., Batista, F., Mollenhauer, K., \& Simnofske, D. (2016). Stiffness characterization of cold recycled mixtures. Transportation Research Procedia, 14, 758-767. https://doi.org/10.1016/j.trpro.2016.05.065

Zofka, A., \& Yut, I. (2011). Alternative procedure for determination of hot mix asphalt creep compliance. Journal of Testing and Evaluation, 39(1), 39-49. https://doi.org/10.1520/JTE102760 